\title{
The importance of social relations in shaping energy demand
}

\author{
Tom Hargreaves ${ }^{1} \&$ Lucie Middlemiss ${ }^{2}$
}

\footnotetext{
${ }^{1}$ [corresponding author], Science, Society and Sustainability (3S) Research Group, School of Environmental Sciences, University of East Anglia, Norwich, NR4 7TJ, UK. tom.hargreaves@uea.ac.uk

${ }^{2}$ Sustainability Research Institute, School of Earth and Environment, University of Leeds, Leeds, LS2 9JT, UK.
}

\begin{abstract}
Current efforts to change patterns of energy demand tend to target people as discrete and isolated individuals. In so doing, they ignore the fact that energy use occurs in places such as homes, workplaces and communities in which complex webs of social relations already exist. Here, we argue that more attention should be paid to how people's social relations influence energy demand. We review recent qualitative research to show how social relations shape how much energy people use, when and where they use it, as well as how they respond to interventions. We propose a typology that identifies three types of social relation as especially significant: those with family and friends, with agencies and communities, and those associated with social identities. We show how a focus on social relations can generate new forms of policy and intervention in efforts to build more just and sustainable energy futures.
\end{abstract}


Humans are social animals: our relationships shape our experiences, decisions and actions. Energy demand is no exception: how we consume energy is shaped by relationships of conflict, consensus, collaboration, companionship, solidarity and oppression with our fellow human beings. When people talk about using energy at home, work or in their communities, they also talk about their relationships with others to explain how and why they consume in the ways they do. Stories of teenagers leaving the lights on, or colleagues being perpetually cold in the office are familiar to us all. It follows that attempts to change patterns of energy demand, to make them more flexible ${ }^{1}$, more just ${ }^{2,3}$, or to help decarbonise energy systems $\mathrm{s}^{4,5}$ depend fundamentally on social relations.

Relational sociology characterises how people act as structured by the situations they are in, others involved in those situations, and their relations with those others ${ }^{6}$. Social relations are therefore seen as shaping, and being shaped by interactions (giving these meaning and significance), reproduced by practices, and important in processes of identity building ${ }^{6-8}$. Social relations shift over time, and the history and expected future of a relationship impact on how it is experienced in the present ${ }^{6}$. People have patterns of social relations, which differ between societies, groups of people and individuals, and which impact on their access to resources. There is a distinction between 'micro' social relationships in daily life (those with parents, friends or teachers) and 'macro' social relationships (such as relationships of class, gender, or belief) ${ }^{8}$, but these intersect and overlap in people's lives.

To help illustrate the multiple ways that social relations shape energy demand, Boxes 1 and 2 provide two vignettes drawn from our own research that show how social relations have diverse impacts on how people access, use and pay for energy as well as how they respond to interventions to manage or reduce energy use. Drawing on stories like these, along with the growing body of evidence reviewed in this Perspective, we have identified three distinct types of social relation which, across diverse contexts and energy-related issues (from smart homes, to community initiatives, to energy poverty), appear to play significant roles in shaping how people engage with and use energy: relations with family and friends, agencies and communities, and relations of identity (Table 1). These three types of relation interact with and cut across each other: people's family relationships are structured by gender relations (relations of identity) as well as by the availability of resources through relationships with agencies and communities. The term 'social relations' has not, for the most part, been commonly used in existing energy literature. There are some overlaps with the concept of social capital which, although contested in itself, broadly refers to the resources that accrue to individuals or groups based on their connections to others and to institutions ${ }^{9}$. We prefer social relations, however, as this theoretical tradition is less instrumental in nature and thus takes a richer and more nuanced approach to the multiple roles and functions of relationships ${ }^{6}$. These three categories are explained in more detail in the following sections.

\section{INSERT BOXES 1 AND 2 ABOUT HERE}


Table 1: Types of social relations impacting on energy demand

\begin{tabular}{|l|l|l|l|}
\hline Social relation type & Definition & Examples & $\begin{array}{l}\text { Impacts on energy } \\
\text { demand }\end{array}$ \\
\hline $\begin{array}{l}\text { Relations with } \\
\text { family and friends }\end{array}$ & $\begin{array}{l}\text { Relationships of care } \\
\text { and intimacy }\end{array}$ & $\begin{array}{l}\text { Parent, child, } \\
\text { husband, partner, } \\
\text { sister, cousin, aunt, } \\
\text { friend, housemate } \\
\text { etc. }\end{array}$ & $\begin{array}{l}\text { Learning and } \\
\text { shaping practices, } \\
\text { sharing energy } \\
\text { services, energy } \\
\text { consumption advice, } \\
\text { lending money etc. }\end{array}$ \\
\hline $\begin{array}{l}\text { Relations with } \\
\text { agencies and } \\
\text { communities }\end{array}$ & $\begin{array}{l}\text { Relationships of } \\
\text { service provision } \\
\text { and activism }\end{array}$ & $\begin{array}{l}\text { Landlords, energy } \\
\text { companies, energy } \\
\text { advice agencies, } \\
\text { tradespeople, } \\
\text { community energy } \\
\text { groups etc. }\end{array}$ & $\begin{array}{l}\text { Energy consumption } \\
\text { advice, energy } \\
\text { efficiency support, } \\
\text { constraints on } \\
\text { choice of tariff or } \\
\text { efficiency measures } \\
\text { etc. }\end{array}$ \\
\hline Relations of identity & $\begin{array}{l}\text { Relationships of } \\
\text { solidarity and } \\
\text { oppression }\end{array}$ & $\begin{array}{l}\text { Age, gender, class, } \\
\text { race, disability } \\
\text { status, single-parent } \\
\text { household, welfare } \\
\text { recipient etc. }\end{array}$ & $\begin{array}{l}\text { Access to support } \\
\text { due to membership } \\
\text { (or not) of a specific } \\
\text { category, practices } \\
\text { shaped by belonging } \\
\text { to that category etc. }\end{array}$ \\
\hline
\end{tabular}

\section{Relations with family and friends}

Our relations with family and friends play multiple roles in shaping when, where and how much energy we use, but this is rarely recognised in policy and decision-making. In research on domestic energy use, for example, the home or household has typically been treated as a mere site of individual behaviour and thus unworthy of attention in and of itself, or as an undifferentiated block that contributes to overall levels of energy demand ${ }^{10}$. That households have shifting internal dynamics, porous boundaries, and are related to others in often complex ways has too often escaped from view ${ }^{11}$. The core social relations in households are those with family and friends. These relations are often based on strong emotional bonds around care, intimacy, love and friendship. These relations are enacted through a range of 'family practices' ${ }^{12}$, a concept generalized to include parenting, friendship and practices of intimacy ${ }^{13}$. It is through the regular performance of these practices that social relations with family and friends have important implications for energy demand. Indeed, households have been characterized as 'micro-level energy systems' each with their own logics and modus operandi. For example, when making decisions about appliance purchases or thermostat settings, householders will likely discuss and negotiate with one another to take account of and respond to specific household properties such as conventions, capacities, rhythms, economies or structures ${ }^{14}$ (see also ${ }^{15,16}$ ). Similarly, households also operate as meso-level 'crucibles' in which interactions between micro and macro-level processes unfold, such as when macro-level concerns about climate change or social justice impact on and are in turn impacted by everyday, micro-scale decisions and actions involving energy use ${ }^{17}$. 
The concept of 'linked lives'18 - that what individuals do is not solely determined by their own preferences but is also shaped by the demands and desires of others ${ }^{19}-$ is useful in understanding how relations with family and friends shape energy demand. The concept emphasises interdependency: how changes in one person's life have implications for others, and for their family and friends (as we see clearly in Box 1). There is a growing body of evidence that shows how daily routines - and the energy demand they generate - are shaped by linked lives and how they evolve throughout the life course. For example, in early parenthood routines are 'anchored' ${ }^{19}$ around the non-negotiable needs of babies and young children for naps, feeding, or to avoid tantrums and manage bedtime ${ }^{20}$. Among families with school age and adolescent children, such concerns evolve to incorporate the fixed timing of the school day, homework, and after-school activities, as well as growing demands for autonomy and privacy giving rise to complex negotiations in which dynamics of conflict, subversion and occasional collaboration play out ${ }^{21}$. Such relations are not exclusive to the home either. At work too, people must negotiate with their friends and colleagues over the thermostat settings in an open plan office ${ }^{22}$ or, increasingly, over whether lights or IT equipment should be on or off ${ }^{23}$.

Wider social trends towards increasing housing costs, housing shortages and growing divorce rates mean that more adults are living parallel lives in their parent's houses ${ }^{14}$, or that children have bedrooms in two households ${ }^{24}$ with associated implications for energy use. Care for elderly relatives is another key stage of linked lives often generating increased needs for heating and daytime energy use ${ }^{25}$. Throughout all stages of the lifecourse, social relations with family and friends are central in shaping which energy-using activities are being engaged in, by how many people, as well as when and where they take place.

Social relations with family and friends also have longer-term implications for energy demand both within and beyond the home. It is through the enactment of these relations, for example, that people become socialised into particular ways of thinking about and using energy and thus that cultural conventions with associated levels of service expectation become normalised and reinforced, or stigmatised and challenged ${ }^{26,27}$. For example, expectations of a comfortable home or a well-cooked meal are established in childhood, as key skills and competences are 'passed on' through the enactment of familial relations ${ }^{13}$. Particular generational and gender roles are also performed (or challenged) in this process, shaping the future distribution of the burden of responsibility for managing energy use, or for thinking about and enacting sustainability ${ }^{24}$.

Social relations among family and friends are also critical in shaping responses to interventions in energy use, and the adoption and use of sustainable energy technologies. For instance, as noted above, families with children can face profound difficulties in shifting their energy use in demand response interventions due to the immediate and immovable demands of infants, or the fixed schedules imposed by school timetables ${ }^{20}$ (also see ${ }^{28}$ ). Studies also reveal strongly gendered patterns of engagement with smart energy technologies with new forms of household labour around researching, upgrading, updating, maintaining and integrating smart technologies often being performed by men ${ }^{29}$. Thus, and as Box 2 shows, whilst they may be attracted by cutting edge technology, the typically male 'lead users' of smart home technologies have to negotiate their functioning with other family members, or ensure they can be operated by children, grandparents, and household 
visitors - a finding echoed across several countries (e.g. ${ }^{16,30-32}$ ). This shapes not only the demand reduction potential of smart energy technologies, but can also give rise to complex and at times troubling household dynamics around control and surveillance. Further, households are not solely energy consumers, but also prosumers, legitimators, citizens and much more besides ${ }^{33}$. Social relations also shape the adoption and use of microgeneration technologies ${ }^{34-36}$ playing a vital role in the unfolding configuration of future sustainable energy transitions. For example, discussions with neighbours can be central to the decision to adopt solar photovoltaic panels, before their use must then be aligned with household dynamics and routines ${ }^{36}$. Efforts to manage or reduce energy demand should therefore treat people as embedded in a web of social relations with their family and friends, rather than as isolated individuals. These relations are central to shaping how much energy people use, when they use it, how they will sustain or challenge cultural conventions of normal energy use, as well as how they will respond to interventions. Generating just and sustainable energy transitions requires new understandings that see energy demand as bound up with these relations rather than separate from them.

\section{Relations with Agencies and Communities}

Our relations with a wide range of different agencies and communities - ranging from energy suppliers, central and local government, through landlords, tradespeople and energy advice services, to community energy groups - shape how much energy we use, as well as what we might do to manage or reduce energy demand, These relations may be formal (legal, contractual) or informal and are based on the provision, management and receipt of energy and energy services as a customer or user, or as a member of a community of place or practice.

One of the most widely discussed of these relations is that between landlords and tenants. Landlords can restrict access to energy tariffs (see Box 1 ) and are recognized as a key obstacle to improving the energy efficiency of rental properties ${ }^{37,38}$. In the UK, vulnerable tenants are found to live in 'fear' of eviction, unwilling to raise concerns ${ }^{39}$ but there are some signs that such relations are changing in other contexts such as New Zealand ${ }^{40}$. In contrast, in the social housing sector, housing associations are often celebrated as sources of low-carbon innovation, seeking to provide efficient homes or forms of microgeneration in part to help reduce tenants' bills ${ }^{36,41}$.

Amongst landlords and owner-occupiers, the challenge is making sense of energy advice and the plethora of technologies available to manage energy use. Here, relations with agencies such as tradespeople, energy suppliers or government authorities - are marked by a significant lack of trust, resulting in active resistance or low take-up of smart meter rollouts or energy efficiency interventions across many different countries ${ }^{42-45}$. In the Netherlands, for example, in the absence of trust in the construction industry, householders turn to their interpersonal relations with families and friends ${ }^{46}$ (see also Box 2 ) or to independent standards and certification schemes before deciding which technologies to install or agencies to recruit (see also ${ }^{47}$ for similar findings in the UK). Vulnerable and socially isolated households fare especially badly here as the presence or absence of such relations may be critical to whether or not they can access key services (see Box 1). This suggests that the role of social relations may be especially significant for disadvantaged groups ${ }^{48}$. Meanwhile, agencies must engage in considerable 'relational work' ${ }^{49}$ to increase trust in their services. 
For example, heating installers mobilise informal social relations within the supply chain to learn about and select technologies for households $s^{50}$. Once inside households, installers must demonstrate personal and adaptive capacities, showing how their advice responds to specific household circumstances and that they have benign and trustworthy motives ${ }^{46,49,51}$. Social relations between households and tradespeople and within supply chains play a significant role in shaping how learning occurs, what advice or technology options are taken up, and how these are used by householders. The result is an inherent conservatism, sticking to 'tried and tested' products and militating against novel low-carbon alternatives ${ }^{50}$.

This lack of trust, and apparent lack of progress towards sustainable energy systems among key agencies may have, in part, given rise to more autonomous community energy initiatives ${ }^{52}$. Cutting across supply and demand side interventions informal, grassroots initiatives serve as spaces in which often radical alternatives - new technologies, business models, or lifestyles - can be experienced and experimented with ${ }^{53,54}$. Whether community based behavior change schemes such as EcoTeams or Carbon Rationing Action Groups, or community renewables projects ${ }^{55-57}$, community energy initiatives have grown rapidly around the world (e.g. ${ }^{58-61}$ ) and have often come to be seen as potentially valuable policy objects. Governments and energy suppliers have thus sought to harness ${ }^{62}$ the social relations inherent to community initiatives to act as trusted intermediaries to communicate interventions in more relatable ways, to depoliticize and increase the public acceptability of proposals, or as a source of volunteer labour ${ }^{63}$. A growing body of qualitative work with such communities, however, has found them to be far from homogeneous or inclusive ${ }^{63,64}$, to demand considerable work from participants often on issues seemingly unrelated to energy itself 65,66 , and to be resistant to capture by outside agencies which may constrain their more critical transformative potential ${ }^{67,68}$. As such, there is a need to attend carefully to the specific and situated social relations embedded in communities when seeking to understand the roles they may play in bringing about just and sustainable energy transitions.

Social relations with agencies and communities shape engagements with and demand for energy in myriad ways, but are constrained by a lack of trust between energy publics and the institutions that serve them. There are many possible reasons for this, but narrow and instrumental framings of energy publics whose sole role is to accept or reject energy innovations offered to them by agencies (so-called 'one-way influence' ${ }^{45}$ ) are insufficient. Instead, it is increasingly recognized that new forms of social relations, involving multiple and diverse forms of influence between 'energy citizens' ${ }^{69}$, agencies and communities need to be cultivated in order to co-produce sustainable energy futures ${ }^{70}$.

\section{Relations of identity}

People's identities shape how they are understood and targeted (or not) by policy and decision-makers, how they see themselves and others, and thus how they interact with family, friends, agencies and their communities. In all of these ways identities play a significant role in shaping energy demand. By relations of identity we mean peoples' association through membership of large social categories (e.g. age, gender, class, race, disability status), or their association through membership of specific types of household (e.g. single/two parent families, single person household). When we belong to social categories, or perform particular roles, this can impact on our energy needs and practices 
(see, for example, Usha in Box 1 as a disabled Asian mother; or John in Box 2 as an engineer, husband and technophile). These can be relationships of solidarity or oppression: people can feel themselves to be linked to others like them, or wish to articulate their distinction from others. People have multiple overlapping and intersecting identities which will be variously salient in different contexts.

While these relations might be determined by having a particular body-type, status, or family structures in common, they are also reflected in policy and practice (thereby impacting on access to state support), and play a role in shaping energy-consuming practices. For instance being an older person in the UK means that you can access state support for withstanding cold weather ${ }^{71}$, but also that you might be uncomfortable wrapping up to keep warm indoors for fear of appearing too 'old' ${ }^{72}$. People's responses to their own identities are important, as they can confound interventions: people behave in unpredictable ways according to their sense of self. Being an older person in Australia might mean that you are reluctant to upgrade appliances to more efficient ones, because that does not fit your self-identity as a 'thrifty' person ${ }^{73}$. While it is impossible to generalise about all people of one 'type', there are frequently patterns in people's energy demand that are structured by membership of a larger social category.

Relations based on identity are heterogenous ${ }^{74}$ : belonging to a category does not mean that you are like all others in that category, or that you want to define yourself in those terms. This is particularly the case when identities are stigmatised (e.g. poverty, disability, single parent). Reid et al., ${ }^{75}$ show how UK domestic energy efficiency projects have become associated with either rich environmentalists, or people living in poverty: in effect being stigmatised as for 'poor' or 'posh' people. This results in a larger threshold for many, demanding they overcome the stigma before engaging in such projects. It is also reminiscent of the practice of bicycling in Bangalore, which is engaged in by both middleclass and working poor people in that city, with very different expectations, aspirations and $\mathrm{kit}^{76}$. In this context, middle-class cyclists make a distinction between their own cycling practices and those that cycle through necessity: thus stigmatising these others in the process. Being at the intersections of a number of identities (see Box 1 for example: being a poor, disabled, Asian single mum) is also likely to have impacts on energy needs, although further research is needed to determine the precise nature of such impacts ${ }^{77}$.

Gendered, generational, and classed expectations also impact on levels and patterns of energy demand, as we saw in previous sections. For example, expectations of how family and community should be 'done', and of how gender roles should be enacted in relationships of care, structure energy demand and determine how interventions are responded to in ways that play out differently in different cultural contexts ${ }^{78,79}$. We can see this in the division of household labour in Box 2. Much work on energy poverty documents how, in trying to be 'good parents', people avoid heating when alone to save scarce resources for their childrens' benefit ${ }^{80-82}$. Community action on energy tends to be led and instigated by the middle classes, which shapes different communities' access to alternative energy resources ${ }^{63,75,83}$. In short, relations of identity are closely intertwined with relations with both family and friends, and with agencies and communities ${ }^{8}$. Acting on these insights demands policy approaches that recognise the salience of different identities in shaping 
energy use and access, and that act to engage rather than stigmatise different groups to work towards more just and sustainable energy transitions.

\section{Future directions}

Our focus on social relations has emerged from sustained use of in-depth qualitative methods to explore the lived experience of energy in multiple sites. Such methods result in nuanced explanations of how and why energy is consumed. For instance, in Boxes 1 and 2, the boundaries of the household are blurred, demand shifts over time in accordance with members' needs, and people face challenges in accessing energy services associated with their multiple identities. This complex web of overlapping social relations, in turn, leads to multiple connections and engagements with wider energy systems as people are simultaneously mothers and (grand)daughters, consumers and citizens, gendered, classed and much more besides. A focus on social relations as the unit of analysis thus requires us to understand energy demand as dynamic and relational. This Perspective has profiled the growing body of work developing these understandings, but there is a pressing need for more research to account for the relational nature of energy demand, as well as to develop situated analyses across different contexts. Such work will provide both a better understanding of people's energy demand needs, how they evolve and change, as well as offering beneficial insights for intervention design.

We have shown how social relations of different types shape energy demand as well as attempts to manage and reduce it. It follows that attempts to realise just and sustainable energy transitions will require both an appreciation of the role of existing relationships in shaping demand, and a willingness to experiment with realigning and developing new relations. This will entail recognising how caring roles evolve throughout the lifecourse, tailoring advice and support interventions to households and families with particular profiles. It will also involve developing smart and energy efficient products in ways that cater for whole families rather than just individual (and often male) lead users ${ }^{16}$, and seeking to stimulate conversation and develop shared family practices and identities around energy saving and sustainability ${ }^{21}$. Our approach requires us to recognise the acute importance of social relations in shielding more marginalised and disadvantaged groups from the worst effects of energy poverty ${ }^{48}$, and thus taking steps to reduce social isolation and bolster local support agencies and communities. It could also lead to interventions into landlord-tenant relationships through legislation and investment to tackle tenant fear and landlord paralysis on energy efficiency ${ }^{40}$, and interventions into the energy market to ensure fairer outcomes for all ${ }^{84}$. Efforts to realign relations with agencies and communities would involve more stringent standards and certification schemes to increase trust in energy advice, appliances and tradespeople, or could seek to use interpersonal networks as more trusted fora for the circulation of energy advice ${ }^{46}$.

A focus on social relations could generate many more suggestions for how policies and interventions might be re-designed. Given the complexity of social relations, however, it is essential not to conceive of them as mere instruments for realising pre-defined policy objectives. Indeed, we would want to avoid narrowly instrumental metrics and evaluations that prescribe particular roles to individuals and communities in energy transitions ${ }^{67}$, so as to recognise the multiple and diverse forms of already existing societal engagement in sustainable energy transitions, and to inspire and cultivate more active energy citizenship ${ }^{70}$. 
A relational approach requires research and policy that sees social relations not as means to an end, but as ends in themselves, and thus develops ways of better understanding, facilitating and resourcing diverse social relations to allow just and sustainable energy futures to emerge.

\section{References}

1. Torriti, J. Peak Energy Demand and Demand Side Response. (Routledge Earthscan, 2015).

2. Baker, K. J., Mould, M. \& Restrick, S. Rethink fuel poverty as a complex problem. Nat. Energy 3, 610-612 (2018).

3. Dobbins, A., Nerini, F. F., Deane, P. \& Pye, S. Strengthening the EU response to energy poverty. Nat. Energy 4, 2-5 (2019).

4. Grubler, A. et al. A low energy demand scenario for meeting the 1.5 degrees $\mathrm{C}$ target and sustainable development goals without negative emission technologies. Nat. Energy 3, 515-527 (2018).

5. Jenkins, K. E. H. \& Hopkins, D. Transitions in Energy Efficiency and Demand: The Emergence, Diffusion and Impact of Low-Carbon Innovation. (Routledge Earthscan, 2019).

6. Crossley, N. Towards Relational Sociology. (Routledge, 2010).

7. Burkitt, I. Social Selves: Theories of Self and Society. (SAGE, 2008).

8. Burkitt, I. Emotions and Social Relations. (SAGE, 2014).

9. Gauntlett, D. Making is Connecting. (John Wiley \& Sons, 2011).

10. Ellsworth-Krebs, K., Reid, L. \& Hunter, C. J. Home-ing in on domestic energy research: 'House', 'home' and the importance of ontology. Energy Res. Soc. Sci. 6, 100-108 (2015).

11. Lane, R. \& Gorman-Murray, A. Material Geographies of Household Sustainability. (Ashgate Publishing Ltd., 2011).

12. Morgan, D. Rethinking Family Practices. (Palgrave MacMillan, 2011).

13. Jamieson, L. Families, relationships and 'environment': (Un)sustainability, climate change and biodiversity loss. Fam. Relatsh. Soc. 5, 335-355 (2016).

14. Bell, S. et al. Sociality and electricity in the United Kingdom: The influence of household dynamics on everyday consumption. Energy Res. Soc. Sci. 9, 98-106 (2015).

15. Hargreaves, T., Nye, M. \& Burgess, J. Keeping energy visible? How householders interact with feedback from smart energy monitors in the longer term. Energy Policy 52, 126-134 (2013).

16. Nyborg, S. Pilot Users and Their Families: Inventing Flexible Practices in the Smart Grid. Sci. Technol. Stud. 28(3), 54-80 (2015).

17. Reid, L., Sutton, P. \& Hunter, C. Theorizing the meso level: the household as a crucible of proenvironmental behaviour. Prog. Hum. Geogr. 34, 309-327 (2010).

18. Elder, G. H. Human agency and social change: perspectives on the lifecourse. Soc. Psychol. Q. 57, 4-15 (1994).

19. Burningham, K. \& Venn, S. Are lifecourse transitions opportunities for moving to more sustainable consumption? J. Consum. Cult. https://doi.org/10.1177/1469540517729010, 1-20 (2017).

20. Nicholls, L. \& Strengers, Y. Peak demand and the 'family peak' period in Australia: Understanding practice (in)flexibility in households with children. Energy Res. Soc. Sci. 9, 116-124 (2015).

21. Collins, R. Keeping it in the family? Re-focusing household sustainability. Geoforum 60, 22-32 (2015).

22. Whittle, R. et al. From responsibility to accountability: Working creatively with distributed agency in office energy metering and management. Energy Res. Soc. Sci. 10, 240-249 (2015).

23. Hargreaves, T. Interacting for the Environment: Engaging Goffman in Pro-Environmental Action. Soc. Nat. Resour. 29, 53-67 (2016).

24. Gibson, C., Head, L., Gill, N. \& Waitt, G. Climate change and household dynamics: beyond consumption, unbounding sustainability. Trans. Inst. Br. Geogr. 36, 3-8 (2011). 
25. Shirani, F., Groves, C., Parkhill, K., Butler, C. \& Henwood, K. Critical moments? Life transitions and energy biographies. Geoforum 86, 86-92 (2017).

26. Henwood, K., Groves, C. \& Shirani, F. Relationality, entangled practices and psychosocial exploration of intergenerational dynamics in sustainable energy studies. Fam. Relatsh. Soc. $\mathbf{5}$, 393-410 (2016).

27. Hansen, A. R. 'Sticky' energy practices: The impact of childhood and early adulthood experience on later energy consumption practices. Energy Res. Soc. Sci. 46, 125-139 (2018).

28. Powells, G., Bulkeley, H., Bell, S. \& Judson, E. Peak electricity demand and the flexibility of everyday life. Geoforum 55, 43-52 (2014).

29. Strengers, Y. \& Nicholls, L. Aesthetic pleasures and gendered tech-work in the 21st century smart home. Media Int. Aust. 166, 70-80 (2017).

30. Hargreaves, T., Wilson, C. \& Hauxwell-Baldwin, R. Learning to live in a smart home. Build. Res. Inf. 46, 127-139 (2017).

31. Mennicken, S. \& Huang, E. M. Hacking the Natural Habitat: An In-the-Wild Study of Smart Homes, their Development, and the People Who Live in Them. Lect. Notes Comput. Sci. 7319, 143-160 (2012).

32. Herrero, S. T., Nicholls, L. \& Strengers, Y. Smart home technologies in everyday life: do they address key energy challenges in households? Curr. Opin. Environ. Sustain. 31, 65-70 (2018).

33. Schot, J., Kanger, L. \& Verbong, G. The roles of users in shaping transitions to new energy systems. Nat. Energy 1, 16054 (2016).

34. Ellsworth-Krebs, K. \& Reid, L. Conceptualising energy prosumption: Exploring energy production, consumption and microgeneration in Scotland, UK. Environ. Plan. A 48, 1988-2005 (2016).

35. Bulkeley, H., Powells, G. \& Bell, S. Smart grids and the constitution of solar electricity conduct. Environ. Plan. A 48, 7-23 (2015).

36. Fox, N. Here comes the sun: the evolution of a prosuming project within a social housing estate. (University of Sussex, 2018).

37. Davis, L. W. Evaluating the slow adoption of energy efficiency investments: Are renters less likely to have energy efficient appliances? in The Design and Implementation of U.S. Climate Policy (eds. Fullerton, D. \& Wolfram, C.) 301-316 (University of Chicago Press, 2012).

38. Ambrose, A. R. Improving energy efficiency in private rented housing: Why don't landlords act? Indoor Built Environ. 24, 913-924 (2015).

39. Ambrose, A., McCarthy, L. \& Pinder, J. Energy (in)efficiency: what tenants expect and endure in private rented housing. A final report to the Eaga Charitable Trust. (2016).

40. Ambrose, A. \& McCarthy, L. Taming the 'masculine pioneers'? Changing attitudes towards energy efficiency amongst private landlords and tenants in New Zealand: A case study of Dunedin. Energy Policy 126, 165-176 (2019).

41. Hoppe, T. Adoption of innovative energy systems in social housing: Lessons from eight largescale renovation projects in The Netherlands. Energy Policy 51, 791-801 (2012).

42. Darby, S. Smart metering: what potential for householder engagement? Build. Res. Inf. 38, 442457 (2010).

43. Hess, D. J. Smart meters and public acceptance: comparative analysis and governance implications. Health Risk Soc. 16, 243-258 (2014).

44. Rosenow, J. \& Eyre, N. A postmortem of the Green Deal: Austerity, energy efficiency, and failure in British Energy Policy. Energy Res. Soc. Sci. 21, 141-144 (2016).

45. Sovacool, B. K., Kivimaa, P., Hielscher, S. \& Jenkins, K. E. H. Vulnerability and Resistance in the United Kingdom's smart meter transition. Energy Policy 109, 767-781 (2017).

46. de Wilde, M. The sustainable housing question: On the role of interpersonal, impersonal and professional trust in low-carbon retrofit decisions by homeowners. Energy Res. Soc. Sci. 51, 138147 (2019).

47. McMichael, M. \& Shipworth, D. The value of social networks in the diffusion of energy-efficiency innovations in UK households. Energy Policy 53, 159-168 (2013). 
48. Middlemiss, L. et al. Energy poverty and social relations: characterising vulnerabilities using a capabilities approach. Energy Res. Soc. Sci. (Under review).

49. Owen, A., Mitchell, G. \& Gouldson, A. Unseen influence - The role of low carbon retrofit advisers and installers in the adoption and use of domestic energy technology. Energy Policy 73, 169-179 (2014).

50. Wade, F., Shipworth, M. \& Hitchings, R. Influencing the central heating technologies installed in homes: The role of social capital in supply chain networks. Energy Policy 95, 52-60 (2016).

51. Wade, F., Shipworth, M. \& Hitchings, R. How installers select and explain domestic heating controls. Build. Res. Inf. 45, 371-383 (2017).

52. Naus, J., Spaargaren, G., van Vliet, B. J. M. \& van der Horst, H. M. Smart grids, information flows and emerging domestic energy practices. Energy Policy 68, 436-446 (2014).

53. Walker, G. \& Devine-Wright, P. Community Renewable Energy: What should it mean? Energy Policy 36, 497-500 (2008).

54. Seyfang, G., Park, J. J. \& Smith, A. A thousand flowers blooming? An examination of community energy in the UK. Energy Policy 61, 977-989 (2013).

55. Howell, R. A. Living with a carbon allowance: The experiences of Carbon Rationing Action Groups and implications for policy. Energy Policy 41, 250-258 (2012).

56. Taylor Aiken, G. (Local-) community for global challenges: carbon conversations, transition towns and governmental elisions. Local Environ. 20, 764-781 (2015).

57. Fisher, J. \& Irvine, K. Reducing Energy Use and Carbon Emissions: A Critical Assessment of SmallGroup Interventions. Energies 9, 1-12 (2016).

58. Pitt, D. R. Harnessing community energy: the keys to climate mitigation policy adoption in US municipalities. Local Environ. 15, 717-729 (2010).

59. Oteman, M., Wiering, M. \& Helderman, J.-K. The institutional space of community initiatives for renewable energy: a comparative case study of the Netherlands, Germany and Denmark. Energy Sustain. Soc. 4, 11 (2014).

60. Klein, S. J. W. \& Coffey, S. Building a sustainable energy future, one community at a time. Renew. Sustain. Energy Rev. 60, 867-880 (2016).

61. Bauwens, T., Gotchev, B. \& Holstenkamp, L. What drives the development of community energy in Europe? The case of wind power cooperatives. Energy Res. Soc. Sci. 13, 136-147 (2016).

62. Walker, G., Hunter, S., Devine-Wright, P., Evans, B. \& Fay, H. Harnessing Community Energies: Explaining and Evaluating Community-Based Localism in Renewable Energy Policy in the UK. Glob. Environ. Polit. 7, 64-82 (2007).

63. Aiken, G. T., Middlemiss, L., Sallu, S. \& Hauxwell-Baldwin, R. Researching climate change and community in neoliberal contexts: an emerging critical approach. Wiley Interdiscip. Rev. Clim. Change 8, e463 (2017).

64. Walker, G., Devine-Wright, P., Hunter, S., High, H. \& Evans, B. Trust and community: Exploring the meanings, contexts and dynamics of community renewable energy. Energy Policy 38, 26552663 (2010).

65. Parkhill, K. A. et al. 'We are a community [but] that takes a certain amount of energy': Exploring shared visions, social action, and resilience in place-based community-led energy initiatives. Environ. Sci. Policy 53, 60-69 (2015).

66. Watts, L. Energy at the end of the world: An Orkney Islands Saga. (The MIT Press, 2018).

67. Smith, A., Hargreaves, T., Hielscher, S., Martiskainen, M. \& Seyfang, G. Making the most of community energies: Three perspectives on grassroots innovation. Environ. Plan. A 48, 407-432 (2016).

68. Creamer, E. et al. Community Energy: Entanglements of community, state and private sector. Geogr. Compass 12, 1-16 (2018).

69. Devine-Wright, P. Energy citizenship: psychological aspects of evolution in sustainable energy technologies. in Framing the present, shaping the future: contemporary governance of sustainable technologies (ed. Murphy, J.) 63-86 (Earthscan, 2006). 
70. Chilvers, J., Pallett, H. \& Hargreaves, T. Ecologies of participation in socio-technical change: The case of energy system transitions. Energy Res. Soc. Sci. 42, 199-210 (2018).

71. Middlemiss, L. A critical analysis of the new politics of fuel poverty in England. Crit. Soc. Policy 37, 425-443 (2017).

72. Day, R. \& Hitchings, R. 'Only old ladies would do that': Age stigma and oldeer people's strategies for dealing with winter cold. Health Place 17, 885-894 (2011).

73. Waitt, G., Roggeveen, K., Gordon, R., Butler, K. \& Cooper, P. Tyrannies of thrift: Governmentality and older, low-income people's energy efficiency narratives in the Illawarra, Australia. Energy Policy 90, 37-45 (2016).

74. Gillard, R., Snell, C. \& Bevan, M. Advancing an energy justice perspective of fuel poverty: Household vulnerability and domestic retrofit policy in the United Kingdom. Energy Res. Soc. Sci. 29, 53-61 (2017).

75. Reid, L., McKee, K. \& Crawford, J. Exploring the stigmatization of energy efficiency in the UK: An emerging research agenda. Energy Res. Soc. Sci. 10, 141-149 (2015).

76. Anantharaman, M. Elite and ethical: The defensive distinctions of middle-class bicycling in Bangalore, India. J. Consum. Cult. 17, 864-886 (2017).

77. Middlemiss, L. \& Gillard, R. Fuel poverty from the bottom-up: Characterising household energy vulnerability through the lived experience of the fuel poor. Energy Res. Soc. Sci. 6, 146-154 (2015).

78. Sahakian, M. \& Bertho, B. Exploring emotions and norms around Swiss household energy usage: When methods inform understandings of the social. Energy Res. Soc. Sci. 45, 81-90 (2018).

79. Hansen, A. R., Madsen, L. V., Knudsen, H. N. \& Gram-Hanssen, K. Gender, age, and educational differences in the importance of homely comfort in Denmark. Energy Res. Soc. Sci. 54, 157-165 (2019).

80. Tod, A. M. et al. Understanding influences and decisions of households with children with asthma regarding temperature and humidity in the home in winter: a qualitative study. BMJ Open 6, 1-14 (2016).

81. Snell, C., Lambie-Mumford, H. \& Thomson, H. Is there evidence of households making a heat or eat trade off in the UK? J. Poverty Soc. Justice 26, 225-243 (2018).

82. Longhurst, N. \& Hargreaves, T. Emotions and fuel poverty: The lived experience of social housing tenants in the United Kingdom. Energy Res. Soc. Sci. 56, 101207 (2019).

83. Anantharaman, M., Kennedy, E. H., Middlemiss, L. \& Bradbury, S. 9 Who participates in community-based sustainable consumption projects and why does it matter? A constructively critical approach. Power Polit. Sustain. Consum. Res. Pract. 178 (2019).

84. Robinson, C. Energy poverty and gender in England: A spatial perspective. Geoforum 104, 222 233 (2019).

85. Hargreaves, T. \& Wilson, C. Smart Homes and Their Users. (Springer, 2017).

\section{Acknowledgements}

This Perspective draws on insights and evidence drawn from several research projects. The authors would like to thank the following funding bodies: the UK Economic and Social Research Council (Grant numbers: PTA-031-2004-00291 \& PTA-026-27-2086); Carbon Connections (Grant number: CC29); the UK Engineering and Physical Research Council (Grant numbers: EP/F022832/1 \& EP/K002430/1) and the White Rose Collaboration Fund (Grant number: $n / a)$. The authors thank all participants across these projects for sharing their insights and everyday expertise. Finally, the authors are grateful to Mary Tallontire (@murkybucket) for providing the illustrations contained in Boxes 1 and 2. 


\section{Competing interests}

The authors declare no competing financial interests. 


\section{Box 1: Vignette of the lived experience of Energy Vulnerability}

Usha was interviewed in 2016 by Middlemiss as part of a pilot study on energy poverty and social relations. Full ethical approval for this study was granted by the University of Leeds Ethics Committee. Accordingly, fully informed consent was provided by all participants and all names are pseudonyms to preserve anonymity.

\section{INSERT IMAGE 1 ABOUT HERE}

Usha, aged 35, lives with her daughter (aged 10) in a small privately rented house in Bradford, UK, which is poorly insulated and maintained. Her daughter helps care for her, as do her siblings and mum who sleep overnight at her house on a rotating basis, as well as paid carers who come in during the day. Usha and her daughter go to live with her mum during school holidays, and her daughter stays with her sister or her ex-husband when Usha is in hospital. Given this rather transient household, it is difficult to say who actually lives with her or where she lives.

Usha has a chronic health condition, similar to MS, following a medical accident and she has very limited mobility, chronic pain, incontinence and low energy levels, resulting in a heightened need for warmth, regular hot water and additional clothes washing. Before the accident she was married, had her own home and worked as a lawyer. Because Usha is registered disabled, she has access to a car through Motability which allows her to take her daughter to school.

Usha depends extensively on her negotiated relationships with others to help her access energy services. For instance, her pre-pay meter needs topping up at the local shop which she cannot easily access alone, she needs help to access the shower, she sometimes cannot get out of bed to take her daughter to school in the morning and asks friends to help. Usha frequently borrows money from family for her energy bills, they are reasonably sympathetic about repayments. A local energy advice service has helped her switch suppliers, but having a prepayment meter is a condition of her tenancy.

Usha was previously fiercely independent, but since the accident has had to rely on others. She hates this. Her descent into poverty has been distressing with regards to her self-image: as an independent and self-sufficient person. Her various identities: as a mother, being from a Pakistani background, being disabled, also impact on her energy consumption and her social life. For instance she wants to cook from fresh for her daughter, she feels it is part of being an Asian mother, but has to be mindful of the associated energy costs. She rarely goes to other people's houses because she needs extra warmth everywhere, and is embarrassed to ask for blankets. She is also embarrassed to invite people to her house because it is not what she would want it to be.

As a disabled person, Usha is living in a time of uncertainty with her status and access to a car under threat as her Disability Living Allowance is converted into Personal Independence Payments. This amounts to an uncertain relationship with the state, and causes intense worry about how she might cope without the extra income and the car. 


\section{BOX 2: Vignette of Smart Technologies in the Home}

John and Jane were interviewed three times during 2013-15 as part of the REFIT Field Trial (see ${ }^{85}$ for details). Full ethical approval for this study was granted by the Loughborough University Ethics Committee. Accordingly, fully informed consent was provided by all participants and all names are pseudonyms to preserve anonymity.

\section{INSERT IMAGE 2 ABOUT HERE}

John and Jane are in their 60s and live in a detached 4-bedroom house in Loughborough, UK. Their children have all recently left home although they regularly care for their grandchildren after nursery or school. John is a semi-retired mechanical engineer who has retained a keen interest in learning about new technologies. Jane is a retired housewife. They follow broadly traditional gender roles. Jane takes charge of the everyday running of the household whilst John oversees household expenditure on things like bills and large purchases. John is very interested in using new technologies to increase control over his home and reduce bills, partly to help save money in retirement. As a result, they already have solar panels (thermal and photovoltaic) and, after talking with a friend that works as a plumber, John decided to participate in a field trial of smart home technologies.

Early in the trial, John is the only one engaging with the smart home technologies. Jane states it hasn't infringed on my life in anyway...it's just there'. She tells John what she wants, such as warm towel rails in the morning, but it is up to John to deliver this. John has happily taken on this role and is initially excited to experiment with the full functionality of the smart home kit. As the trial unfolds, Jane starts to express frustration that she no longer knows how to control their heating. She recounts stories of when their son stayed at Christmas and was woken by whirring radiator valves in the middle of the night, and a time when their daughter and granddaughter let themselves into a cold home, couldn't work out how to turn the heating on, so waited in the car with the engine running until John returned home. In effect the technology has increased the family's reliance on John to access energy services. As the trial unfolds Jane becomes increasingly irritated with the technologies, feeling monitored by unknown others in a home she can no longer control.

By the end of the trial John expresses exasperation at the poor user-friendliness of the system which has stopped him from getting the most out of it. He feels the trial technologies fall way short of the cutting-edge smart home kit he reads about in technology magazines. He's especially keen on developments in voice control technology in this regard, but is concerned that such technological advances may come with higher financial costs that will outweigh potential savings. 


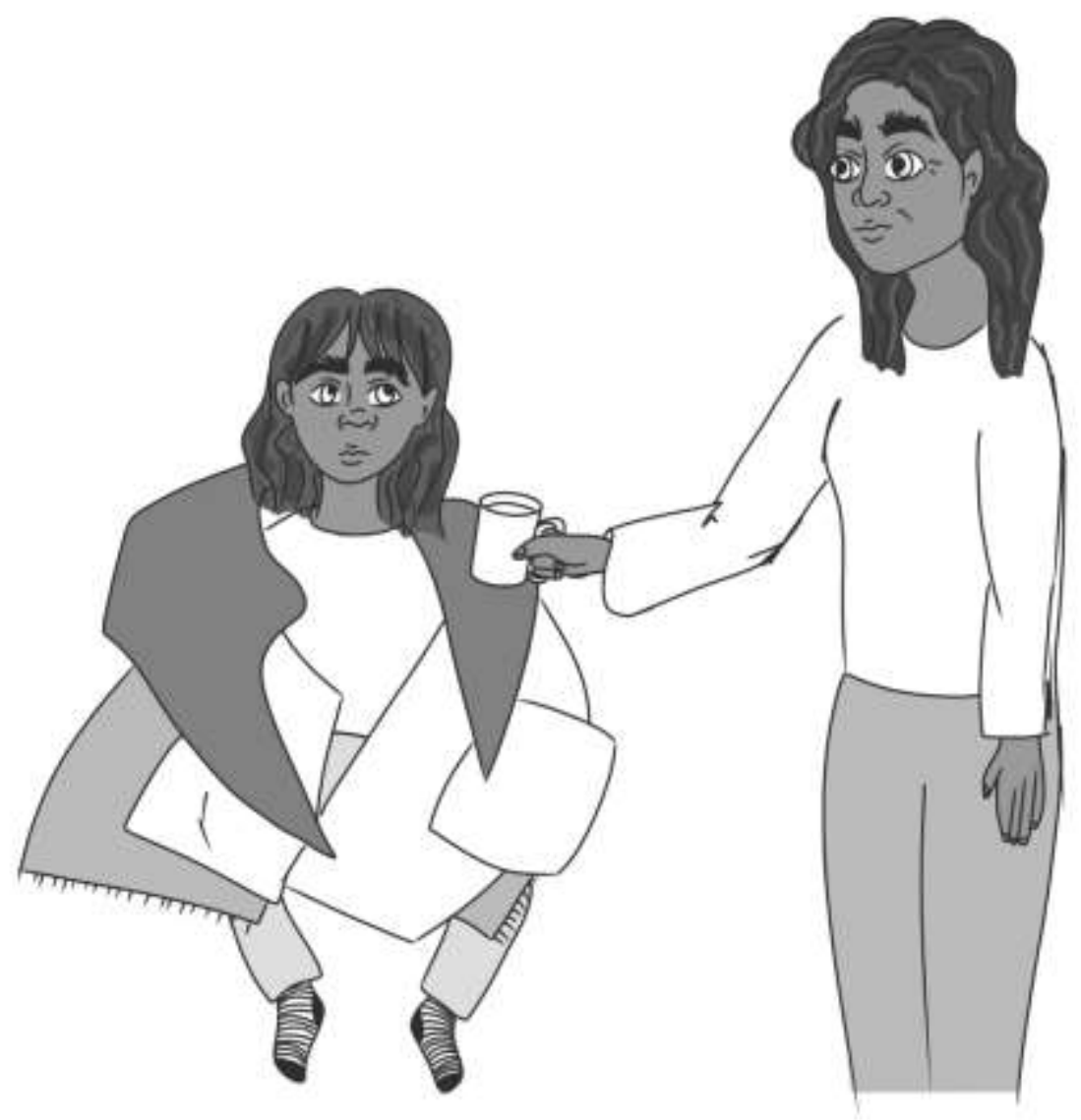

Image 1 

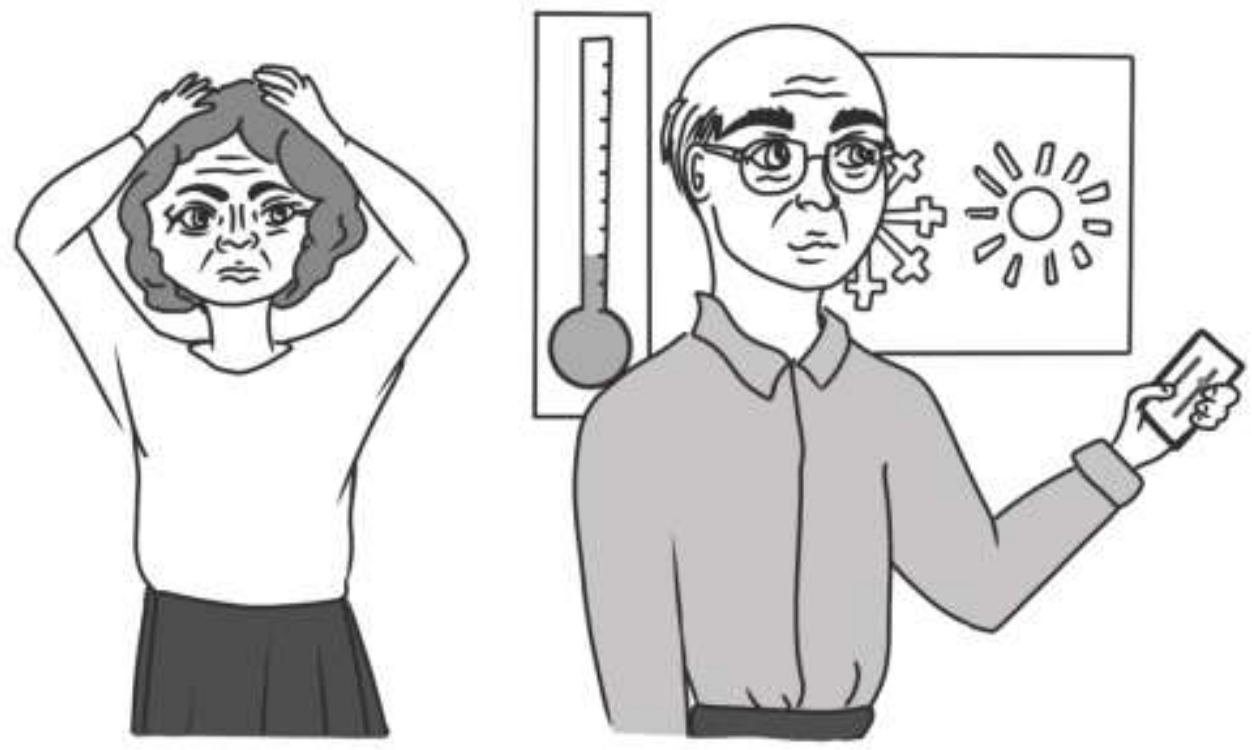

Image 2 